\title{
The Problem of the Position of Natural Person in the Process of BankRuptey in the Context of European
}

\section{INTEGRATIONS}

\section{Abstract:}

Individual bankruptcy, as a procedure of preferential bankruptcy procedure reserved for natural person, often leads to problems in application, which are a consequence of not understanding the essence of the institute or often bad implementation of application instruments, where all of this then leads to paradoxical inability to apply the institute.

This paper will emphasize the basic problems which appear when the subject of the bankruptcy procedure is a natural person. Author will analyze it through the problem of insolvency of individuals and factual inability to

realize payment of creditors. It will be analyzed based on the following aspects: this matter is unregulated in Serbian law; then a comparative overview of the issue of the position of an insolvent artisan in croatian law, and the issue of abuse of rights which are used by the citizens of EU through the institute "bankruptcy tourism". Based on this comparative analysis, the author will try to provide suggestions with the goal of progress of at least partial payment of the creditors by the individual debtor in the bankruptcy process. This Article will provide specific suggestions which the future Iegislation of Serbia should deal with, and which will be based on the critical overview of the foreseen institute of individual bankruptcy in Croatian law, which is not used in practice.

\section{Keywords:}

individual bankruptcy, natural person, European integration

\section{Author's data:}

1 Opačić Ana, PhD (Assistant Professor), Faculty of Business Economics and Entrepreneurship, Belgrade, Mitropolita Petra 8, ana.galjak@gmail.com

International Journal - VALLIS AUREA • Volume 1 • Number 1 • Croatia, June 2015

UDK [347.736:347.15]:061.1EU; DOI 10.2507.IJVA.1.1.8.8 


\section{Introduction}

It is impossible to give a complete definition of over indebtedness, which is directly linked to the subjects who create this over indebtedness. The consequences that are created due to over indebtedness of natural persons are not only of economic nature, manifested in impossibility of servicing their debt, but they also have a sociological and psychological aspect, which creates new expenses for the entire society.

When we are talking about legal person as the subject of the bankruptcy, it is clear that the goal of the procedure is to provide at least partial payment to the creditors along with the system of general realization on the total assets of the debtor, which causes a consequence of cessation of subjectivity of a legal person. $\$ 0$, a specific real subject ceases to exist by finalizing the bankruptcy procedure. Legal person, who cannot service his obligations, should be erased from the commercial register and cease to exist because that is according to the strengthening of legal certainty. However, would an analogue application to all natural persons be appropriate in case of insolvency? And would it be appropriatenot only for the consumers but also for the natural persons registered to conduct economic activities, like entrepreneurs in Serbian Law, artisans and traders in Croatian Law? Natural person who conducts economic activities is an economic entity, so if he is faced with inability to keep the liquidity of business and is late with payments or he becomes absolutely insolvent, he would have to have an alternative besides the simple enforcement proceedings, which is available to Serbian entrepreneurs. There are many reasons to justify this claim. Firstly, how one should approach to the situation of absolute insolvency when setting the procedure in motion only creates new debt, and thus increases the existing overall debt, that will never be paid; how one should handle a huge number of unpaid claims that can have an effect of chain reaction of insolvency for all the clients of over indebted person; in which way to provide obeying of the Constitution guaranteed dignity of an individual in the procedure that is forced by nature; in which way to realize a just division among the creditors in the procedure in which the time sequence is most important and where a more aggressive creditor has greater possibility of getting paid. The basic problem with natural person who practices economic activity in the insolvency procedure is his limitless responsibility, prying of the executor into personal assets of an entrepreneur, where conducting economic activities carries the risk of losing a home and existence.

The reality that has been warning us in the last couple of years that the lack of systematic consideration of the problem of insolvency of natural person causes the present statistics which shows that in 2014 significantly less new entrepreneurs were registered in Serbia and artisans in Croatia, that the trend of late payments is increased, the overall debt is also increased in long-term blockage of economic entities llonger than 5 years]. Serbia and Croatia are fighting the same problems but in different space and time frame, but the essence is the same. We should decrease the state apparatus and make it more efficient and profitable from the state budget point of view, and on the other hand encourage the development of private entrepreneurship as a framework of economic development. It is utterly desirable to have a specific goal, however, is it necessary to realize it and in what way when the instruments for conducting those ideas are unavailable. How we should encourage the development of entrepreneurship and what should be the pillar of future economic development or the recovery of the state, when we approach to it with negation of the basic issues entrepreneurs face. 
How to expect them to enter an economic match, when in case of eventual failure, nothing else is guaranteed besides basic guarantees given by the enforcement proceedings in respect of exception of execution. It is necessary to systematically, through the law that regulates the procedure of founding and registration of legal person and bankruptcy law, provide instruments that will motivate entrepreneurs not to hide assets in order to deceit executors, to really show the profit, that will generally motivate the sector of "grey economy" to be narrowed. For realizing these goals, it is necessary to offer something, within legal solutions, to the entrepreneur in the form of stimulations, like decrease of tax levy but also through creating the "safety net" in the situation of liquidity and insolvency problems. This procedure should certainly only be applied to those persons who are honest in their situation, i.e. which should be interpreted according to the phrase "honest but misfortunate debtor", and thus avoid the possible abuses by entrepreneurs.

Therefore, it is necessary to conduct an analysis of the existing problems that insolvent persons and their creditors are faced with, and based on the criticism of the current legal solutions to try and give some suggestions for decrease of insolvency of the economy, which is currently an issue for Serbia and croatia and this represents the basic author's motive in the further text of this paper.

\section{The position of a natural person in case of insolvency in Serbian Law}

Natural person cannot be the subject of the bankruptcy according to the Serbian law. Law on bankruptcy of Serbia states in the article 1, that only legal person can be the subject of bankruptcy [1]. By this definition bankruptey law of Serbia made a discontinuity with bankruptcy solution from 2004 [2], which defined the possibility of executing bankruptcy procedure on legal and natural person who conducts economic activities entrepreneur. So the reform done in 2009 in the field of bankruptcy did not continue to develop and perfect the establishing of individual bankruptcy institute, but the bankruptcy procedure over the assets of a natural person, in Serbian law, has become impossible, even though the real indicators of growing over indebtedness of citizens and disincentive of entrepreneurs advocate the implementation of this institute.

The citizens of Serbia loaned around five billion euros in credits from the banks, where most of them are mortgage loans $3.2 \mathrm{bn}$. According to the data of Credit Bureau of the Association of Serbian Banks, every citizen is indebted to the banks and leasing companies in the amount of 837 euros, loans are 749 euros, overdrafts 35 euros, credit cards 47euros, leasing services 6 euros [3]. If we compare these data with the data of the Association of banks from 2012, we can see that there is an insignificant increase of debt per capita from 814 euros in 2012 to 837 at the end of 2013. Total indebtedness of Serbian citizens and economy for bank loans is decreased by $5.1 \%$ in 2013 and is 2,140bn dinars, where the indebtedness of companies is decreased by $8.2 \%$ and is 1,414 bn dinars. Indebtedness of citizens by the bank loans is increased by $2.8 \%$ and is $616.37 \mathrm{bn}$ dinars, however if we take into consideration the inflation rate we notice the stagnation in citizen indebtedness [3].

If we look at the loan structure of citizens the biggest decrease can be seen in consumer loans by $18.3 \%$, while cash loans increased by $14.4 \%$ [4].

By considering strictly the statistics we would surely come to a wrong positive conclusion in respect of movements of the trend of indebtedness of the citizens of Serbia. What masks this statistics is the trend of increasing later in 
payment of the loans of citizens, entrepreneurs and legal persons.

According to the data of Credit Bureau of the Association of Serbian Banks until 30.11.2014 $20.6 \%$ of legal persons was more than 15 days late in paying their payment obligations, which shows a significant growth compared to 2013 when the percentage was $15.4 \%$. Entrepreneurs also follow the trend of rate growth later in their payments, so that percentage in 2013 was 16.3\% and in 2014 21.7\%. The citizens of Serbia also had more difficulties paying the payment obligations, so there we also see the growth trend of rates later in paying the loans. Even $6.8 \%$ of citizens, in 2014, were late with payments of their obligations for more than 60 days, which shows us a trend of growth of $1.8 \%$ when compared to 2013 [5].

Taking into account all data we can notice the decrease of credit activity which will continue in the next year as well, if we do not get significant investments in economy, because the economy does not own its own means which can be used for investing and it is forced to be financed from the loans and the number of economic entities suitable for obtaining a loan is decreasing. The decrease in loan activity causes the decrease in investments and the inability to develop the economy of a country.

Without a systematic approach to solving the problems of over indebtedness of natural persons we will soon have an alarming statistics of losing homes as the consequence of execution, psychopathological manifestations in respect of increase in the number of suicides, and the numbers are already alarming.

According to the data of Statistical office of Serbia, in 2009 there were 1376 suicides, and in 2013 1198. During the analysis of these data we also have to take into consideration the negative population growth where in 2011 65,598 were born and 102,935 died, and the same trend continues in 2013 when
65,554 were born and died 100,300 [6]. If we look at the number of people born and those who took their own life by suicide we get the final number of $2 \%$, of all the born people, committed suicide, of people born in 2013. Nobody has the statistics of suicides among the entrepreneurs, but the numbers have become alarming. Entrepreneurs who face business failure, sudden poverty, loss of image, loss of homes because of activating the safety measures (mortgage), and often psychological torture and threats to them and their families by the usurers, decide to opt for this method of finalizing entrepreneurial activities. According to the data of Serbian Union of Employers for the period 2004-2010, 75 entrepreneurs chose suicide as an epilogue to their business careers [7]. If we add that, unfortunately, more and more often entrepreneurs see the way out of the over indebtedness in suicide, it is obvious that it is high time for us to consider the problem of effects of permanent insolvency on the natural person. Also considering the data got from Serbian Business Registers Agency for 2013, where a large number of entrepreneurial companies was closed by the newly founded ones, and the existing entrepreneurs instead of dealing with economic reintegration and ways of financial restructuring, of course together with the assistance of the state, they create the ugly statistics of this country, leaving behind not just psychologically negative consequences to the family, but also serious debt for the society.

The problem of piled, unregulated debt which is a serious battle for the economy of Serbia has Iong-term consequences for the overall society. By stating that a debt cannot be regulated, that the payment is impossible because there are no means, leaves the creditor without his means, but also creates the effect of insolvency that is passed on to others, which can, directly or indirectly, jeopardize the creditor and push him to insolvency. 
Considering that it is necessary to encourage development of entrepreneurial spirit and to take care of entrepreneurs at the market, at the same time, it is necessary to legally regulate the procedure in case of insolvency within the bankruptcy law, which will give long-term effects.

According to the current Law on companies, entrepreneur is a natural person who registers himself for conducting economic activities and he vouches for his business by his entire assets, including his home [8].

One new thing about this law is that debt responsibility does not stop only by erasing from the register, for example by suicide an entrepreneur is erased by the law, but the article 85 of the law, paragraph 2 says that even though the entrepreneur is erased he is still responsible and vouches with his assets [8]. However the Law on companies does not oblige an entrepreneur to own any kind of property, but only to provide the means necessary for the functioning of a company. Due to this, nowadays, it is often that entrepreneurs behave in misleading way, where they register and do business, while they do not have anything from the assets on their name, so when they are faced with insolvency, the creditors do not have the material for execution and at least get the partial payments. It is obvious that the existing system is dysfunctional and that it cannot realistically meet the needs of the economy in transition. One time decision to cancel the payment of rates and piled debts, one time arrangements with the banks in respect of trying to refinance and debt rescheduling, obviously do not give results.

By creating a bankruptcy procedure for natural persons, for entrepreneurs with forecasting of "new financial beginning" and implementation of the institute in respect of liberation from unpaid debts, we would humanize the position of an entrepreneur and strengthen the financial responsibility of market participants. Considering that the rules that one must obey the contract obligations, there is a question of what happens with all obligations which stay unfulfilled due to the statement that there are no means to execute them.

Implementation of the bankruptcy procedure for natural persons showed that it has many benefits. The critics often put the system of individual bankruptey in the context of social giving and creating new expenses for the state, but the truth is completely opposite. Systems of bankruptcy have been designed for individuals who are able to create enough profit to sustain themselves and their families; however the problem is that piled debt undermines their initiative and decreases their productive capacity. These debtors do not seek stronger intervention in their lives, but smaller intervention in respect of constant conducting of overpriced and destructive procedures of collection of debt. The goal is not to receive financial or other support, but to stop counterproductive procedures of forced debt collection [9]. The essence of differing the welfare system and system for fighting the insolvency is that the problem of poverty cannot be solved by establishing a single procedure, while the practical issues of insolvency are being solved in that particular way [9]. A well-structured and wellfunctioning bankruptcy system should facilitate to those debtors who absolutely need it and it should be available in a short timeframe. Every welldesigned bankruptcy system will foresee the fulfilment of certain requests as a precondition for entering into bankruptcy system. If it is determined that even the decrease of the debt will not lead to its payment, even with all the measures which encourage self-reliance of the debtor, bankruptcy procedure should, in the short timeframe, facilitate for the debtor to apply the institute of debt relief [10]. Relatively quickly after the end of a bankruptcy procedure, majority of 
debtors should again be financially stable and they would not be expected to ask for this support again, since this procedure should, besides financial reintegration, educate in respect of strengthening of financial responsibility. It is highly likely that, in the following period, the legislator will approach solving this issue more seriously and form a Iegislation which will in detail regulate the bankruptcy procedure for the assets of natural persons in Serbia.

\section{Artisan in Croatian law and practice}

Individual bankruptcy is announced in Croatian law in its full form, as a proceeding of benefited procedures, which can be used by all categories of natural persons. However, when it got the form of legal text they saw that they deviated from the Basic foundations for introducing the institute of individual bankruptcy from 2011 and they opted for a narrower regulation of natural person's bankruptcy.

The current Croatian bankruptcy law, in the very first article, where it determines the subject of this law, mentions the institute of debt relief as a possibility guaranteed to the debtor individual, which represents the framework of the individual bankruptcy institute [11]. The third article determines the debtor individual as a trader and an artisan [11]. So, the croatian law opted for a narrower form of application of individual bankruptcy, to acknowledge this right only to natural persons who conduct economic activities. Analysis of application of the insolvent procedure to the artisan would be incomplete without the interpretation of the regulation which regulates turnover. Law on turnover, article 2, defines the notion of turnover as an independent and permanent conducting of economic activities with the goal of gaining profit by production, selling or providing services at the market [12]. Regulations of the law which are important for the needs of this paper are the regulations on the responsibility of artisans for their business, which are regulated by the article 36 of this law. The law determines artisan as a natural person in registered business who vouches with his all assets, like in Serbian law, however in certain paragraphs of the same article, there is a more detailed definition of responsibility, which gives certain safety to the natural person to decide to conduct economic activities. Therefore, article 36 of this law, paragraph 2, says that execution with the purpose of finding financial means cannot be done on those assets and rights, on which execution could not be done if he was not conducting economic activities. As well as on those assets and rights which are necessary for conducting of his economic activities, if it is his main source of means for business operations [12].

Serbian legislators should take this Iegislation, on guaranteeing the preservation of the basic means for business operations during execution, into consideration, because it provides support to individual bankruptcy procedure in respect of encouraging the artisans to create new value, and by doing so he can service the creditors.

Essential legislation which guarantees a home to a natural person, if faced with financial difficulties during doing business as an artisan, can be found in paragraph 3 of the same law.

Execution for realization of financial claims against an artisan cannot be done on his real estate where he lives, but only in the scope of satisfying the basic needs of the debtor and other people the debtor is obliged to support [12]. This legislation made a significant step towards guaranteeing safety of the home to the debtor, towards humanization of debtor's position and also towards preventing the expenses that would be created for the state by creating more people who have to use welfare. They also had in mind that they have to be careful about possible abuses, so 
they put as an option, selling a larger home, getting a smaller one and using the difference to pay creditors. However, if the creditor, based on voluntary legal business with the artisan gained a lien or a similar right of insuring the claims, artisan cannot opt for execution procedure for the ban on home alienation [12].

The law that has to be taken into consideration during the analysis of artisan's position in Croatian law is the Law on financial transactions and pre-bankruptcy settlement [13]. Procedure of pre-bankruptcy settlement is a procedure which is done with the goal of establishing liquidity and solvency of the debtor. This law foresees this procedure as obligatory for legal persons and individual debtors. The pre-bankruptcy settlement procedure is started only on the request of the debtor, and he has to suggest it in two cases: if the debtor cannot obtain the state of liquidity within 60 days from the start of measures of financial restructuring, excluding the pre-bankruptcy settlement, and if 21 days passed from the start of his insolvency [13]. There is a difference between the regular and shortened pre-bankruptcy settlement procedure. The shortened prebankruptcy settlement procedure is opened if there are two cumulative conditions fulfilled: that the overall amount of obligations is not over $2 \mathrm{ml}$ kuna, and that the employer employs less than 30 employees.

The pre-bankruptcy settlement procedure is an emergent procedure and it has to end in front of settlement council within 120 days from its opening, besides from the fulfilling the conditions for its elongation for another 90 days. The shortened pre-bankruptcy settlement procedure has to be ended within 100 days from its opening [13].

Law on financial transactions and prebankruptcy settlement proved to be very faulty, with much space for manipulation and abuse which makes it hard to conduct it in practice. Very few settlements were closed, and parties that made a pre-bankruptcy settlement rarely fulfil their obligations regularly [14].

I will not go into further analysis, when it comes to legal persons, to what extent the obligatory pre-bankruptcy settlement contributed, and to what extent it just prolonged the inevitable creating of more expenses. Every failure of prebankruptcy settlement leads to opening the bankruptcy procedure. There is a question of justification of application of this law, especially in the situation when we are talking about a natural person who conducts economic activities. Then we are actually talking about doubling the procedure, because the croatian bankruptcy law foresees the procedure of individual bankruptcy, so the artisans and traders individuals should not be found in pre-bankruptcy settlement procedures.

The individual bankruptcy procedure which is foreseen in the text of Croatian bankruptcy law, foresees the measures which strongly resemble to the ones foreseen by the rules of pre-bankruptcy settlement. When we are considering artisans, it seems that the full application of the bankruptcy law and chapter VIII would give much better results than autistic persistence of pre-bankruptcy settlement. Artisan who is faced with inability to pay has to, according to the Bankruptcy law; submit a proposal for starting the bankruptcy procedure. To be more precise, people who represent the debtor in front of the law, and individual debtor have to submit a proposal for opening a bankruptcy procedure within 21 days from the day when he is unable to pay, and he is responsible for the damage caused to the creditors by not fulfilling his duty defined by that Iegislation [11]. Along with the proposal for opening bankruptcy procedure over his assets, the debtor must submit the proposal for debt relief. By asking 
for debt relief he accepts to do a debt rescheduling in the period of 7 years, because there is no automatic relief in Croatian law. In the situation where it is clear that the debtor cannot pay back to his creditors, and Law on crafts as we have seen guarantees means for business operations which can create new value and continue to do economic activity, is it not better to oblige debtor to submit a proposal for opening bankruptcy procedure over turnover and to be obliged to make payments to the creditors during 7 years according to the established order.

The debtor's position in bankruptcy procedure is the same as in pre-bankruptcy settlement; he has limited business ability and has to fulfil a sequence of severe criteria to get liberated. Firstly, before opening bankruptcy procedure, bankruptcy judge names the creditor on the assets of debtor, to whom the debtor gives all the transferable claims based on labour and other appropriate current claims to the period of time of seven years after the closure of bankruptcy procedure. The cession is decided about by the bankruptcy judge by the decision on liberation [11].

During the period of 7 years, the so-called period of good behaviour, the creditor is obliged to keep the amounts, that he receives on account of cession and all other payments which benefit the debtor or a third party, separately form his own assets and once a year to divide them among creditors based on final list. In order to motivate the debtor to stay productive, because the period of good behaviour is difficult for the debtor (he only gets means necessary for a simple life], the law determined that the debtor will, after 4 years from the closure of bankruptey procedure, provide $10 \%$, after 5 years $15 \%$ and after six years $20 \%$ of the amount that he receives based on cession or other obligatory payments [11].

Article 291 of this law regulates in detail the obligations of the debtor during this period, where there is an emphasis on the obligation of the debtor to create new value, which accomplishes multiple goals. Firstly, the debtor is economically recovered; he is reintegrated into the market, while on the other hand he is obliged to work in order to create new value from which he can service the creditors. Then the measures which have a goal to prevent abuses are foreseen, and which motivate the registration of all his profits, and not to go into "grey economy", where he would make his assets inaccessible to the creditors. They also foresee a great number of reasons to deny this liberation, even when the decision on liberation becomes final, it can be revoked if it is determined that the debtor had an intention or done fraudulent action with the goal of causing damage to the creditors [11].

Considering that there are such wellstructured bankruptcy procedures for artisans as forms of individual bankruptcy, is it not better, in cases of insolvency, to open bankruptcy procedure immediately, and start making periodical payments to the creditors, because individual bankruptcy does not have stopping of turnover as a goal, but financial recovery, which is the purpose of pre-bankruptcy settlement.

The pre-bankruptcy settlement has proven to be inefficient in respect of turnover faced with absolute insolvency, where there are no assets from which creditors could get paid at least partly. There are one time fiscal reliefs, which only add to the state's expenses.

opting for individual bankruptcy in these situations means to affirm such turnovers and make them continue those activities, which encourages the economy itself. By debt relief, debtors are motivated to create new value for creditors in the period of 7 years, to register assets and profits, not to hide them like they do nowadays with the goal of inability to pay. Instead of doing one time reliefs to citizens for receipts for utilities 
(electricity, water, heating...), the state should approach to procedure of debt relief for the narrows circle of those who are absolutely bankrupt, with the goal of affirmation of this procedure's usage or creation of the solidarity fund as is the case comparatively, which would finance procedures of individual bankruptcy for those artisans who underwent economic collapse. By doing so they have a chance for economic recovery, while in the opposite case, they will again become a problem and expense for the state in the form of one more person who uses welfare.

\section{Overview of the absence of harmonization of Bankruptcy laws of the Member States of the EU}

Within the EU law frame there still is not the law that has a goal of regulating of matter of individual bankruptcy, the bankruptcy where a subject is natural person, the consumer. The EU member states including Croatia have regulated the possibility, the way and procedure of opening individual bankruptcy procedure, which resulted in great number of different legislative solutions [15]. European Union tends to harmonize laws, including bankruptcy laws in other state members. Until this harmonization is not achieved, the citizens of the EU member countries can legally declare individual bankruptcy and to opt for application of the most appropriate legislative solution of any member country to their legal situation.

Treaty on the functioning of the European Union guarantees the right to the freedom of movement and settling inside a unique market, overcoming the national borders of countries that keep legislative authority in their territory. Until the field of material law remains unharmonized, the possibility of competition among different legislatures is always present, as well as moving with the goal of using the favourable bankruptcy law is enabled. As the Treaty on the functioning of the European Union guarantees the freedom to the citizens of EU to move from one member state to another, there is a question of whether every movement is connected to the purchase of authority. Phenomenon dominant in Great Britain, because of significantly more liberal bankruptcy procedure, is the so-called bankruptcy tourism, which is basically purchase of authority i.e. the search for the most favourable bankruptcy law. [16] After subjects become indebted and insolvent in one member country they seek to move the centre of their actual business operations or to create the impression that they have moved it to another member state in order to start the main procedure there and get debt relief according to the bankruptey law of that state which offers benefits in relation to their country of origin. Moreover, the debtors can choose the bankruptcy law which is mild towards debtors, which will have a negative reflection throughout $\mathrm{EU}$, including the state where the original centre of business operations was i.e. the country where the debt was created [17].

Every case of bankruptcy involving a foreign citizen, who led his business operations on the territory which is under the authority of another legislature, creates practical difficulties and additional expenses for creditors and institutions like courts, bailiffs and creditors for bankruptcy issues. It is certain that it is more expensive and more difficult to find and make a list of assets, research possible bases for a law suit and identify creditors, when the centre of bankruptcy is in another country, the one where the centre of actual business operations was.

In 2011 World Bank conducted preliminary research, and the work group, in its report in 2014, defined the issue of insolvency of natural persons as a system risk, and pointed out the need for modernization of the law and institutions in 
certain countries, in order to enable the authorities to fight the risks of over indebtedness of natural persons in an effective and efficient way. It is essential to recognize various approaches to solving this issue, values, culture preference of certain society and legal tradition, which condition the access of authorities to the issue of over indebtedness [18], and according to this to try and create the bases of getting the legislation closer to the EU, in order to prevent the guaranteed liberties to grow into abuses.

\section{Conclusion}

The equality of all subjects in front of the law imposes the equal treatment of all participants in economic relations regardless of their status of legal or natural person. Individual bankruptcy is not an ideal, but it is the end tool in the situation when there is no other way for an individual to pay his debts.

During the previous decades, legislators have fought with many negative effects caused by the growing trend of over indebtedness of natural persons. These problems have spread across regions which differ a great deal, not just in cultural, historical and social structure, but also in economic and business development.

Over indebtedness and piling of unregulated debts, which is the case with Serbia and croatia, represents a serious economic issue and a system risk. It causes the fall in productivity of great part of population burdened by debts, which undermines individuals' initiative and decreases their capacity for debt payment. Statistical data, which have already been analysed, show the trend of growth of indebtedness of natural persons, as well as the trend of being late with servicing their obligations. The decrease of number of new entrepreneurs in Serbia is obvious, as well as artisans in croatia, while there is a trend of growth of closing enterprises every year.
Serbia is at the very beginning, even though the public talks more and more about the need to implement individual bankruptcy into the law, while Croatia on the other hand has all the instruments in its hands, which it needs to start implementing. Having that goal, it is necessary to approach the harmonization of the existing laws, because there are differences in regulating the same institutes, and we should also consider changing the law on financial business and prebankruptcy settlement where the individual debtors, trader individual and an artisan, would be excluded from this procedure, and included in the individual bankruptcy procedure.

\section{References}

[1] Law on bankruptcy, Official Gazette RS, no.104/2009, 99/2011 - other law, 71/2012 - decision US and 83-2014.

[2] Law on bankruptcy, Official Gazette RS, no. 84/04.

[3] Credit Bureau, Association of Serbian Banks, Available from: http://www.ubsasb.com/Default.aspx?tabid=9927 Accessed: 2015 01-13

[4] Credit Bureau, Association of Serbian Banks, Available from: http://www. ubsasb.com/Portals/0/vesti/146/30-11-14-4.pdf

Accessed: 2015-01-13

[5] Credit Bureau, Association of Serbian Banks, Available from: http://wWw. ubsasb.com/Portals/0/vesti/146/30-11-14-5.pdf Accessed: 2015-01-13

[6] Statistical Office of Serbia, Overview of the data of deaths and births, Availablefrom:http://webrzs.stat.gov.rs/Website /Public/ReportResultView.aspx?rptKev=indld\%30 180104021NDO1\%2C18010402IND02\%26102\%3dRS \%2623\%3000\%2620\%3d201100\%2c201300\%266sA reald\%33d18010402\%26dType\%3dName\%26|Type \%3dSerbiancyrillic Accessed: 2015-01-13 
[7] Official web page of Union of Employers of Serbia, Available

from:

http://www.poslodavci.org.rs/aktivnosti/projekti /publikacije Accessed: 2015-01-14

[8] The Law on Companies, Official Gazette of RS, no. 36/2011 and 99/2011, 83/2014

[9] Kilborn, J. [2008). Comparative Cause and Effect: Consumer Insolvency and the Eroding Social Safety Net. The Columbia Journal of European Law, Vol. 14, No. 3(563-596).

[10] Kilborn, J. [2011]. The alternative to bankruptcy is not payment, but waste, uncertainty and chaos. Cayman Financial Review, Available from: http://WwW. compasscayman.com/cfr/2011/00/05/ The-alternative-to-bankruptcy-is-not-payment,but-waste,-uncertainty-and-chaos/ Accessed: 2015-01-14

[11] Law on bankruptcy of RC, NN 44/96, 29/99, 129/00, 123/03, 82/06, 116/10, 25/12, 133/12.

[12] Law on Crafts of RC, NN 143/13.

[13] Law on financial transactions and prebankruptcy settlement, NN 108/12, 144/12, 81/13, 112/13.

[14] Čuveljak, J. (2014). Pre-bankruptcy settlement and bankruptcy, Available from: http://www. iusinfo.hr/DailyContent/Topical.aspx ?id=17553 Accessed: 2015-00-14

[15] Opačić, A. [2011]. Regulation of individual bankruptcy in EU law, European law, №.37-38, pg.68.

[16] 0'Sullivan, A.l 2009]. UK could face wave of bankruptcy

tourism.

Availablefrom:http://www.thisismoney.co.uk/ne ws/article.htm|?in_article_id=489549\&in_page_id= 2 $;$; Accessed: 2015-01-14

[17] Singh, R. [2009). Bankruptcy tourists exploit UK's Ienient insolvency laws. Available from:http://www. accountancyage.com/aa/news/ 174884//bankruptcy-tourists-exploit-uks-lenientinsolvency-laws Accessed: 2015-01-14
[18] World Bank. (2014) Report on the Treatment of the Insolvency of Natural Persons. Available from: https://openknowledge.worldbank.org/bitstream /handle/10986/17606/ACS68180WPOP120BOX0382094B OOPUBLICO.pdf?sequence=1 Accessed: 2015-01-15 


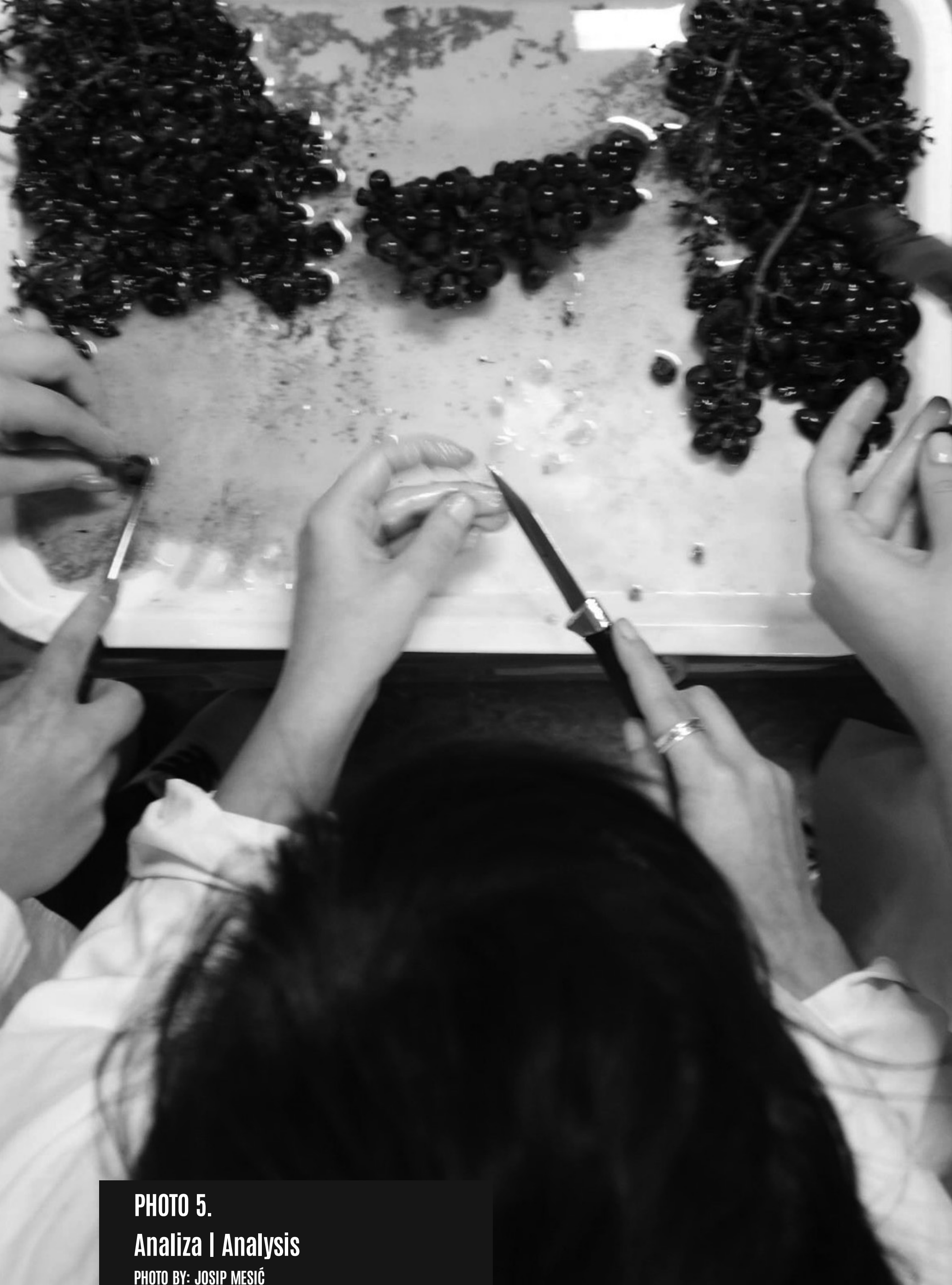

PHOTO BY: JOSIP MESIĆ 